\title{
ピッチ系サブミクロン炭素繊維不織布の作製
}

\section{Fabrication of a mesophase pitch-based submicron carbon-fiber web}

\author{
北野高広 ${ }^{a), b)}$, 岩田 彰 ${ }^{\mathrm{b})}$, 沖野不二雄 ${ }^{\mathrm{c}), *}$
}

Takahiro Kitano $^{\text {a),b) }}$, Akira Iwata ${ }^{\text {b) }}$ and Fujio Okino ${ }^{\text {c), * }}$

\begin{abstract}
A mesophase pitch-based submicron carbon-fiber web, non-woven fabric, was prepared using an aqueous solution of polyvinyl alcohol (PVA). The dispersion of mesophase pitch in the PVA solution was electrospun to form a web of submicron carbon fibers. The carbon-fiber web was heat-treated at $2800^{\circ} \mathrm{C}$ in argon. The diameters of the carbon fibers were 200 to $800 \mathrm{~nm}$. The XRD peak near $2 \theta=26^{\circ}$, which corresponds to the (002) diffraction peak of graphite, was broad and at slightly lower angle compared to that of the graphite powder because of the less crystalline nature and the smaller size of the mesophase pitch-derived graphitic particles. TEM observation indicated that the fiber consists of aggregates of mesophase pitchderived small graphitic particles surrounded by an amorphous substance likely originating from the PVA.
\end{abstract}

KEYWORDS : Mesophase pitch-based carbon fiber, Electrospinning, Carbon-fiber web, Non-woven fabric, Polyvinyl alcohol

\section{1. 緒 言}

これまでいろいろな繊維径の炭素瀻維を用いた不織布が検討 されており，さまざまな分野での応用が検討されている。繊 維径が5 15 $\mu \mathrm{m}$ 程度の炭素繊維を用いた不織布はすでに市販 されており，固体高分子形燃料電池（Polymer Electrolyte Fuel

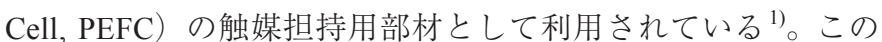
サイズの炭素繊維不織布は短繊維の炭素繊維不織布をバイン ダーで結着した後，焼成する製法が一般的である ${ }^{2)}$ 。一方，繊 維径が数nmのカーボンナノチューブからなる不織布も数多く

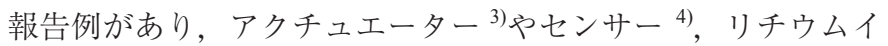
オンキャパシタらなどへの利用が検討されている。このサイ ズの炭素繊維不織布は，たとえば単層カーボンナノチューブ （Single-Walled Carbon Nanotube, SWNT）の場合はいったん溶媒 に分散させた後，万過して薄膜を作製する方法が報告されてい る ${ }^{3)}$ 。また，SWNTの分散液を基材上に塗布して溶媒を乾燥さ せて薄膜を得る方法 ${ }^{6}$ も報告されているが，これも不織布の一 種とみなすことができる。

上記，炭素繊維不織布の製法は短瀻維を用いたものが主流で ある。一方で長繊維炭素瀻維からなる不織布の作成法もいくつ か報告されている7),8)。報告されている長繊維炭素瀻維からな る不織布の製造方法に共通していることは，ポリアクリロニト リル (polyacrylonitrile, PAN) を有機溶媒に溶解し, 静電紡系法
（Electrospinning method, ESP）により基板上に繊維径がサブミ クロン（100～1000 nm）の不織布を作製し，これを炭素化して PAN系炭素繊維不織布を作製するという方法である。

ところで，直径 $10 \mu \mathrm{m}$ 前後の炭素瀻維ではPAN系とピッチ系 炭素繊維があるが，PAN系炭素緎維が主流であり，その低密 度, 高比強度, 高比弾性率を生かして宇宙航空機工業を中心に 幅広く利用されている9)。ピッチ系炭素繊維はその高剛性と金 属同等以上の高い熱伝導率を活かして産業分野などで用途が広 がっている。

ところが上述のように，ESP法によるサブミクロン炭素瀻維 不織布の作製は主にPAN系に限られており，ピッチ系につい てはほとんど検討されていない。今回，ESP法によるピッチ系 サブミクロン炭素瀻維不織布の作製およびその物性評価を行っ たので報告する。水溶性高分子であるPVAを用いることによ り有機溶媒を必要としない，環境にやさしいプロセスを採用す ることができた。

\section{2. 実 験}

炭素瀻維不織布は以下の工程にて作製した。まずポリビニ ルアルコール（ポバール，PVA-224，株式会社クラレ製；けん 化度：87 89 mol\%, 重合度：約 2400）とメソフェーズピッチ (MCP-350, JFEケミカル株式会社製; 融点：325 375 ${ }^{\circ} \mathrm{C}$, 固 定炭素：80\%以上）が重量比率で $2: 1$ とした水溶液を印加電圧

* Corresponding Author, E-mail: fuokino@shinshu-u.ac.jp

(平成24年2月27日受理, 平成24年6月6日採択)

a) 平松産業株式会社：干929-012 石川県能美市浜町又161-4

Hiramatsu Sangyo Co.: 161-4 Nu, Hamamachi, Nomi, Ishikawa 929-0124, Japan

b) 信州大学大学院総合工学系研究科 : 干 386-8567 長野県上田市常田3-15-1

Interdisciplinary Graduate School of Science and Technology, Shinshu University: 3-15-1 Tokida, Ueda, Nagano 386-8567, Japan

c) 信州大学繊維学部：=386-8567 長野県上田市常田3-15-1

Faculty of Textile Science and Technology, Shinshu University: 3-15-1 Tokida, Ueda, Nagano 386-8567, Japan

http://dx.doi.org/10.7209/tanso.2012.160 

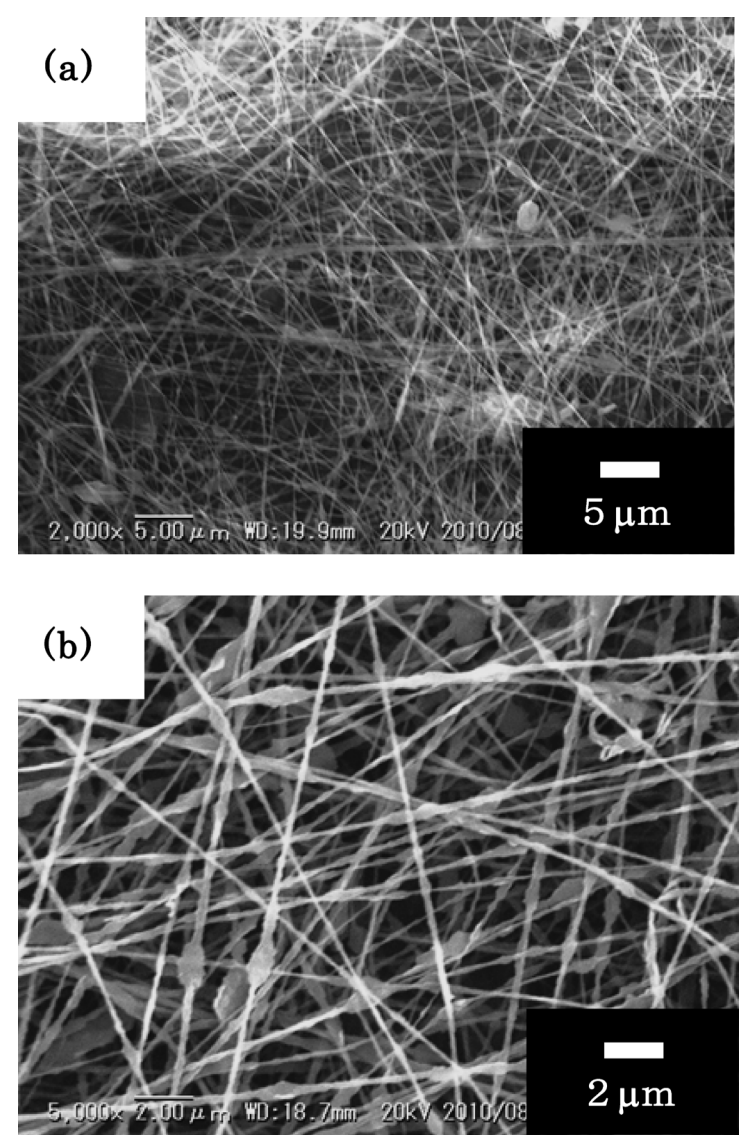

Fig. 1 SEM images of the electrospun mesophase pitch-based carbon-fiber web. (a) $2000 \times$ and (b) $5000 \times$.

$10 \mathrm{kV}$ ，ターゲットまでの距離 $10 \mathrm{~cm}$ としてエレクトロスピニ ング法（Nanospider ${ }^{\mathrm{TM}}$ ，NSLABエルマルコ株式会社製）にて紡 糸して不織布を得た。次いで空気中 $300{ }^{\circ} \mathrm{C} て ゙ 1$ 時間熱処理した 後, アルゴン雲囲気下で $900{ }^{\circ} \mathrm{C}$ (昇温速度 $5{ }^{\circ} \mathrm{C} / \mathrm{min}$ ), $2800{ }^{\circ} \mathrm{C}$ （昇温速度 $10^{\circ} \mathrm{C} / \mathrm{min}$ ) にて熱処理を行った。 $2800{ }^{\circ} \mathrm{C}$ の熱処理 には超高温電気炉（SCC-110/150，倉田技研製）を用いた。

得られた不織布の構造解析は, 走査型電子顕微鏡観察（Scanning Electron Microscope, SEM; S-5000 Hitachi), 透過型電子顕 微鏡観察（Transmission Electron Microscope, TEM; H-9000NAR Hitachi, $300 \mathrm{kV}$ )，ラマン分光測定 (Hololabo5000 KAISER, $532.18 \mathrm{~nm}, \mathrm{Nd}$ : YAG laser) とX線回折測定（X-ray diffraction, XRD: RINT2200 RIGAKU, CuK $\alpha=154.18$ pm), BET法比表面積 測定 (Brunauer-Emmett-Teller (BET) method; Autosorb-1, Quantachrome）によって行った。

\section{3. 結果と考察}

Fig. 1 に，得られた不織布の熱処理前のSEM像を示す。繊維 の直径は約 $200 \sim 500 \mathrm{~nm}$ であり，1 $\mu \mathrm{m}$ 程度の節状の塊が所々に あることがわかる。この不織布を, 空気中 $300{ }^{\circ} \mathrm{C} て ゙ 1$ 時間, ア ルゴン雲囲気下で $900{ }^{\circ} \mathrm{C}$, さらに $2800{ }^{\circ} \mathrm{C}$ て熱処理を行った ところ，不織布は縦，横共に約 $50 \%$ 収縮した。熱処理後の不織 布についてのSEM 観察結果を Fig. 2に示す。繊維の直径はおよ そ200～ 800 nmであり，Fig. 1(b) と Fig. 2(b) を比較すると，熱処
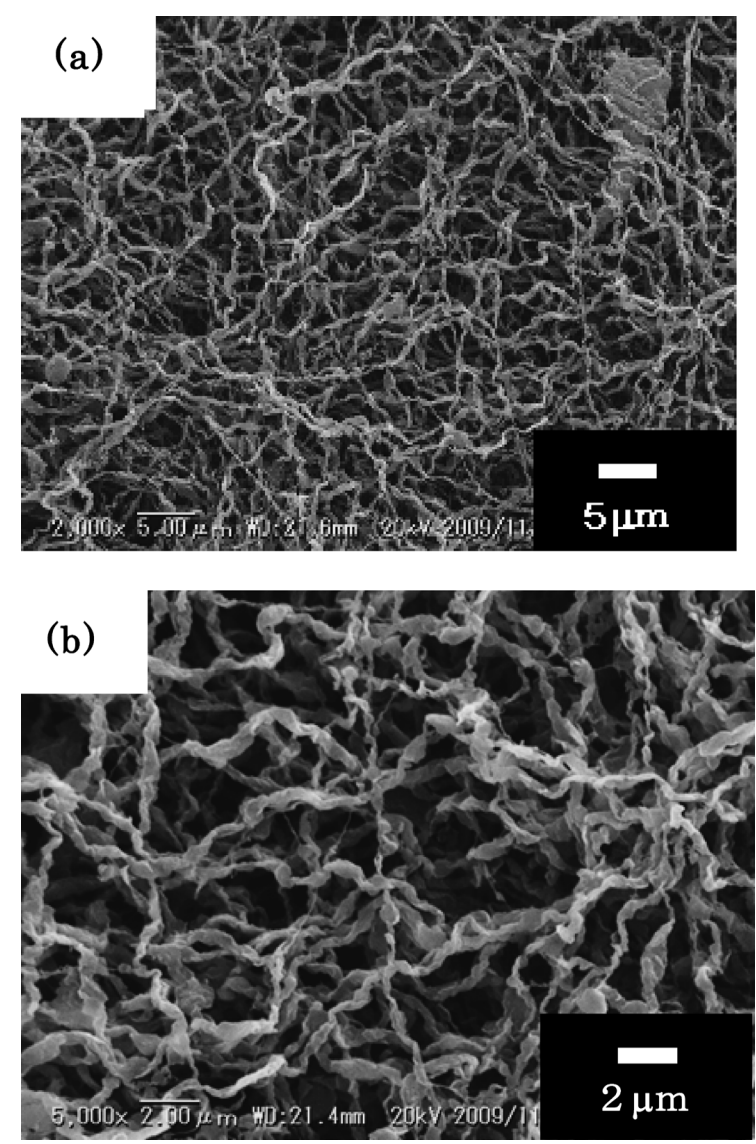

Fig. 2 SEM images of the mesophase pitch-based carbon-fiber web heat-treated at $2800{ }^{\circ} \mathrm{C}$. (a) $2000 \times$ and (b) $5000 \times$

理によって繊維が収縮しており，これが節と節の距離の変化と 考えられる。重量は，熱処理前に比べ $32 \%$ まで減少している ことより，繊維中に含まれていた大半のPVAは，熱処理によっ て消失したと考えられる。熱処理後の繊維はジグザグ形状をし ていた。これはPAN系炭素繊維7) とは形状が異なる。PAN系炭 素繊維の場合，繊維はPANからなる均一組成のため $2500^{\circ} \mathrm{C} ま$

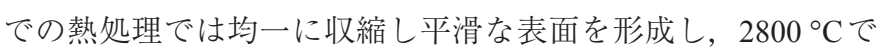
の熱処理では表面にしわが見られ，断面の形状は多面体とな

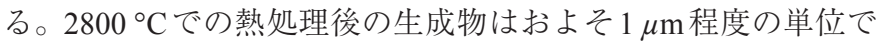
折れ曲がりが生じているが，これは黒鉛化が進んだピッチ微粒 子が，複数で折れ曲がりの単位を形成したものと思われる。

比較として, Fig. 3に, PVA/ピッチの混合比 4:1で作製し $2800{ }^{\circ} \mathrm{C}$ に熱処理した試料の SEM像を示す。この場合は，混 合比 $2: 1$ で作製したものに比べて，ジグザグの度合いが少ない ことがわかる。これは，ピッチの含有量が大きいほうが熱処理 前に節が多くでき，それがジグザグやねじれの原因になった可 能性があることを示している。

Fig. 4に2800 ${ }^{\circ} \mathrm{C}$ に熱処理を行った不織布の TEM像を示す。 Fig. 4(a)において䋊維軸は右上から左下に向かっており，炭素 繊維はメソフェーズピッチ由来の微結晶からなる集合体である ことがわかる。結晶は繊維の方向に関係なくランダムに配置 されていた。ただし, 長さが $200 \mathrm{~nm}$ 以上の比較的大きな結晶 はやや繊維軸に沿って配向しているように見える。Fig. 4(b)で 


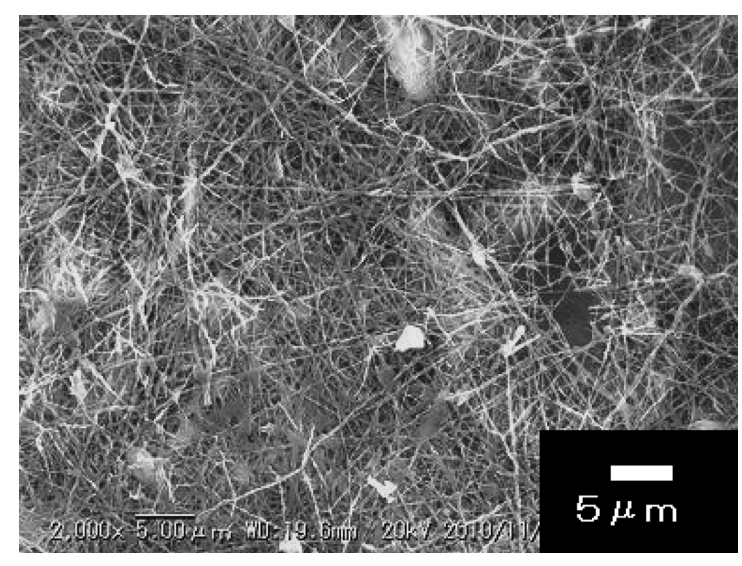

Fig. 3 SEM image of the mesophase pitch-based carbon-fiber web prepared with the weight ratio of PVA : pitch $=4: 1$ and heattreated at $2800{ }^{\circ} \mathrm{C}$.

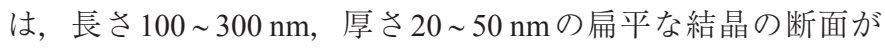
観測できる。結晶はグラファイト層が数十枚積層して形成され ており, 眓中の矢印で示すように，グラファイト層の末端は巻 き返した構造をしている。

Fig. 5に，不織布および比較として用いた黒鉛粉末（アルド リッチ社製）のラマン分光測定の結果を示す。 $1355 \mathrm{~cm}^{-1}$ 付近 にアモルファスカーボンや黒鉛結晶端に由来する Dバンドが観 察され, $1580 \mathrm{~cm}^{-1}$ 付近にグラファイト由来の $\mathrm{G}$ バンドが観察 された。 $\mathrm{G}$ バンドのピーク強度を基準に規格化して Dバンドの 強度を比較したところ不織布と黒鉛粉末でほぼ同じであった。 本不織布にはPVAの熱分解物由来のアモルファスカーボンと 黒鉛化度がそれほど高くはないメソフェーズピッチ由来微粒 子が含まれるためにDバンドの吸収があり，黒鉛粉末ではサン プル表面にエッジが多いためDバンドの吸収が大きくなってい る。また， $1605 \mathrm{~cm}^{-1}$ 付近にフォノンの状態密度に関係した $\mathrm{D}^{*}$ バンドが観測された ${ }^{10)}$ 。この D*バンドは，Dバンドと同様に グラファイト構造の欠陥が多い程, 高い強度を示すことが知ら れている。
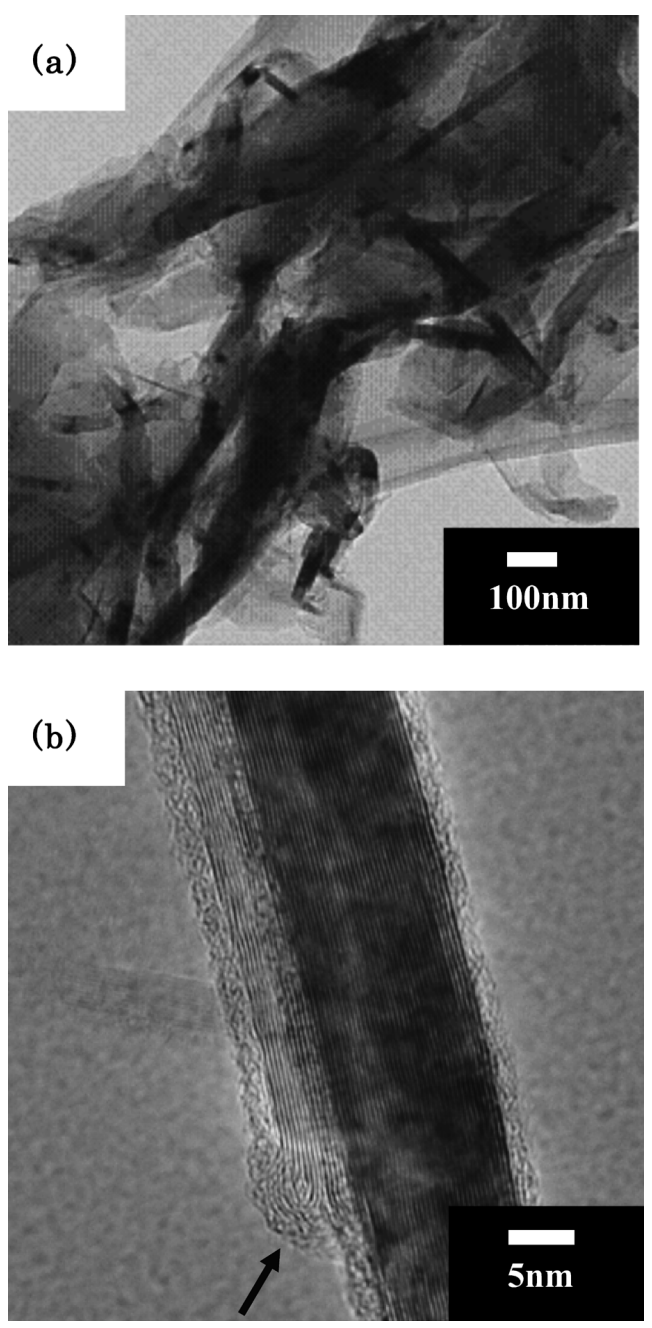

Fig. 4 TEM images of the mesophase pitch-based carbon-fiber web heat-treated at $2800^{\circ} \mathrm{C}$. (a) $20000 \times$ and (b) $500000 \times$.

Fig. 6に，得られた不織布および比較として用いた黒鉛粉末 のX線回折測定の結果を示す。図中に指数が示してあるが，不 織布の $2 \theta=43^{\circ}$ 付近のブロードで非対称なピークは (10) バン ドであり不織布中のメソフェーズピッチ由来微粒子は乱層構造

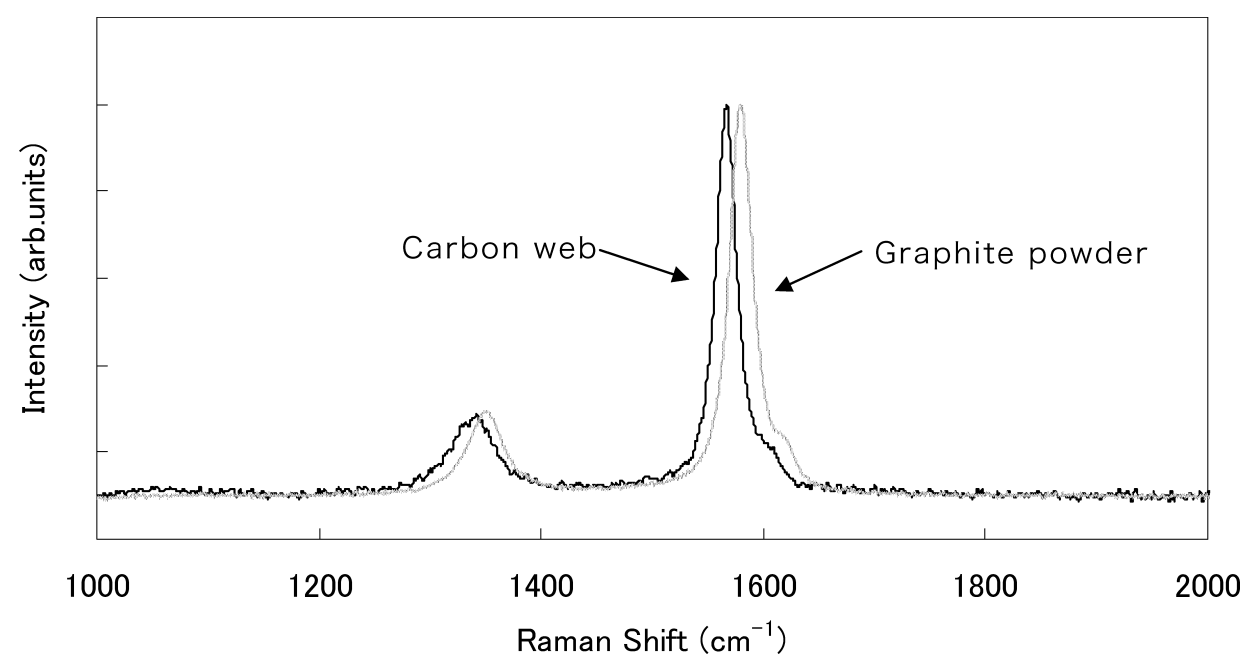

Fig. 5 Raman spectra of the mesophase pitch-based carbon-fiber web heat-treated at $2800{ }^{\circ} \mathrm{C}$ and the graphite powder. 


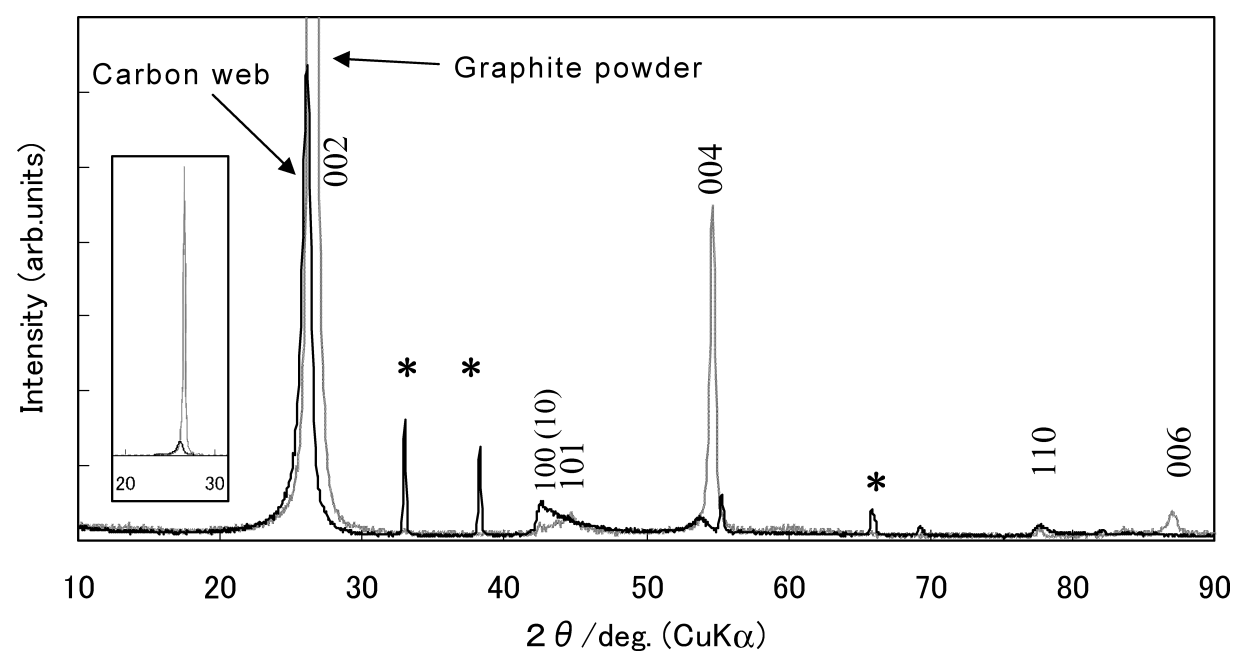

Fig. 6 XRD patterns of the mesophase pitch-based carbon-fiber web heat-treated at $2800{ }^{\circ} \mathrm{C}$ and the graphite powder. The inset covers the full peak of the graphite powder 002 reflection.

Table 1 Structural parameters for the graphite powder and the mesophase pitch-based carbon-fiber web.

\begin{tabular}{lcccc}
\hline & $d_{002^{\mathrm{a}}}(\mathrm{nm})$ & $L_{c}^{\mathrm{a})}(\mathrm{nm})$ & $R_{\mathrm{I}}\left(I_{\mathrm{D}} / I_{\mathrm{G}}\right)^{\mathrm{b})}$ & Surface $^{\mathrm{area}}{ }^{\mathrm{c})}\left(\mathrm{m}^{2} / \mathrm{g}\right)$ \\
\hline Graphite powder & 0.336 & 42.6 & 0.287 & 16.7 \\
Carbon-fiber web & 0.341 & 11.4 & 0.294 & 10.4 \\
\hline
\end{tabular}

a) The average interlayer spacing $\left(d_{002}\right)$ and the crystallite size $\left(L_{c}\right)$ were obtained by XRD measurement using the Bragg and Scherrer formulae, respectively. b) $R_{\mathrm{I}}$ is the ratio of the intensity of the D-band to that of the G-band obtained from the Raman spectra. c) Surface area was determined by BET method.

をなしていることがわかる。また，図中で星印をつけたピーク は，原料のメソフェーズピッチのみを熱処理したものにも観測 されることより，ピッチ由来のものであることまでは確認でき たが明確にはわかっていない。不織布の002回折ピークは, 比 較した黒鉛粉末に比べてブロードで強度が低く，低角側にシフ トしていることがわかる。これはFig. 3(b)で示したように不織 布はアモルファスカーボンを含み, かつ黒鉛化度がそれほど高 くはないメソフェーズピッチ由来微粒子の結晶子サイズが小さ いためである。

Table 1に，比較として用いた黒鉛粉末と得られた不織布の 炭素六角網面層の層間距離 $\left(d_{002}\right)$, 六角網面積層方向の結晶 子サイズ $\left(L_{c}\right)$, ラマンスペクトルの $\mathrm{D}$ バンドと $\mathrm{G}$ バンドの強 度比 $\left(R_{\mathrm{I}}\right)$, 比表面積を記す。黑鉛粉末と比較して不織布の $d_{002}$ は大きく，L $L_{c}$ は小さいことがわかる。

不織布の結晶子サイズが黒鉛粉末と比べ小さかった理由は

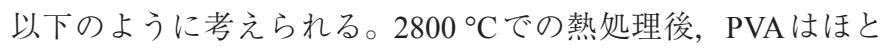
んど消失してピッチ微粒子が溶融結合することが予想された が, TEM像（Fig. 4) よりピッチ微粒子が溶融結合していなこ とがわかった。その理由として, ピッチ微粒子の周りのPVA は, ピッチ微粒子の存在によって熱分解が阻害され, 単体PVA に比べて熱分解しにくいのではないかと考えた。ピッチの融点 は約 $350^{\circ} \mathrm{C}$ であり, この温度ではPVAはすでに炭素化が始まっ ている。したがって, $350^{\circ} \mathrm{C}$ 近辺で熱処理を行っている時点で 溶融して可塑性のあるピッチの微粒子の周りには炭素化しつつ あるPVAがあり，そのようなPVAは単体PVAに比べて熱分解 しにくいため, ピッチの微結晶が結合して大きな結晶にならな
いまま，各ピッチ微粒子の炭素化・黒鉛化が進行したのではな いかと推測される。たとえば，ピッチ微粒子表面のカルボキシ 基とPVAのヒドロキシ基のエステル結合によってPVAが架橋 され，PVAの熱分解が抑制されることなどが考えられる。しか しながら，ピッチ微粒子が溶融結合しなかった理由やPVAの 関与についてはさらなる検討が必要である。

不織布の比表面積は黒鉛粉末に比べて小さいことがわかっ た。これは，黒鉛粉末ではエッジなどがむき出しのために比 表面積が大きくなっているのに対し，本不織布では，TEM像 （Fig. 4）からわかるように，黒鉛化した各ピッチ微粒子がおそ らくはPVA由来と考えられる熱分解物に囲まれているために 比表面積が小さくなったと考えられる。

以上のことより，本研究で得られたピッチ系サブミクロン 炭素繊維の形成過程は以下のようなものであると考えること ができる。PVAの中に分散していたメソフェーズピッチ微粒子 は熱処理過程において大半のPVAが熱分解により消失してい くとともに集合する。 $350^{\circ} \mathrm{C}$ 近辺では，溶融して可塑性のある ピッチの微粒子の周りには炭素化しつつあるPVAがあり, そ のようなPVAは単体PVAに比べて熱分解が抑制される可能性 があり，ピッチの微結晶が溶融結合して大きな結晶にならない

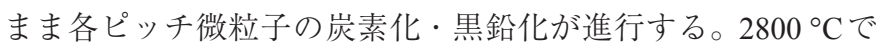
の熱処理後の生成物はおよそ $1 \mu \mathrm{m}$ 程度の単位で折れ曲がりが 生じている場合があるが，これは黒鉛化が進行した長さ100 $300 \mathrm{~nm}$, 厚さ $20 \sim 50 \mathrm{~nm}$ のピッチ微粒子が, 複数で折れ曲がり の単位を形成したものである。

ところで，天然黒鉛や人造黒鉛はスマートフォンなどのモバ 
イル機器の電源やハイブリッド自動車, 電気自動車の電源とし て利用が拡大しているリチウムイオン電池の負極活物質として 用いられている。これは炭素六角網面層間にリチウムイオンが 可逆的にインターカレーション可能であり層間化合物を形成す るためである。現在リチウムイオン電池に求められている性能 の一つに出力特性の向上・充電時間の短縮がある。これを改善 する方法の一つに単位時間あたりにインターカレーションでき るリチウムイオンの数を増やす, すなわち負極活物質の比表面 積を増やすことが考えられる。現在リチウムイオン電池の活 物質として使われている黒鉛の比表面積は $3 \sim 4 \mathrm{~m}^{2} / \mathrm{g}^{11)}$ であり, 今回検討した不織布の表面積はその3 倍以上である。この点を 考慮して今後, 本不織布の電気化学特性についても評価してい く予定である。

\section{4. まとめ}

ポリビニルアルコールとメソフェーズピッチを原料としてエ レクトロスピニング法を用いて直径200～800 nmのピッチ系サ ブミクロン炭素繊維不織布を作製し，その構造解析を行った。 炭素繊維の構造はメソフェーズピッチ由来の微結晶の集合体で あることがわかった。また, PAN系炭素繊維ではPANが水に 溶けないため有機溶媒を利用しなければならないが，本報告で は水溶性高分子であるPVAを用いることができたので，有機 溶媒を使用する必要がなく，環境にやさしいプロセスを採用す ることができた。

\section{謝 辞}

本研究は（独）新エネルギー・産業技術総合開発機構 （NEDO）から受託したプロジェクト「平成 21 年度 新エネル ギーベンチャー技術革新事業」に関するものである。関係者の 皆様に感謝の意を表する。また，貴重なご助言をいたたいた信 州大学繊維学部の後藤康夫先生に謝意を表します。

\section{文 献}

1) Y. Wang, C. Wang and K. S. Chen, Electrochim. Acta 52 (2007) 39653975.

2) R. B. Mathur, P. H. Maheshwari, T. L. Dhami, R. K. Sharma and C. P. Sharma, J. Power Sources 161 (2006) 790-798.

3) J. Fraysse, A. I. Minett, O. Jaschinski, G. S. Duesberg and S. Roth, Carbon 40 (2002) 1735-1739.

4) M. D. Rein, O. Breuer and H. D. Wagner, Compos. Sci. Technol. 71 (2011) 373-381.

5) B. J. Landi, M. J. Ganter, C. M. Schauerman, C. D. Cress and R. P. Raffaelle, J. Phys. Chem. C 112 (2008) 7509-7515.

6) T. Kitano, Y. Maeda and T. Akasaka, Carbon 47 (2009) 3559-3565.

7) C. Kim, K. S. Yang, M. Kojima, K. Yoshida, Y. J. Kim, Y. A. Kim and M. Endo, Adv. Funct. Mater. 16 (2006) 2393-2397.

8) M. Li, G. Han and B. Yang, Electrochem. Commun. 10 (2008) 880-883.

9) K. Naito, Y. Tanaka, J. Yang and Y. Kagawa, J. Am. Ceram. Soc. 92 (2009) 186-192.

10) J. Jiang, R. Saito, A. Grüneis, S. G. Chou, G. G. Samsonidze, A. Jorio, G. Dresselhaus and M. S. Dresselhaus, Phys. Rev. B 71 (2005) 045417.

11) Y. Ishii, T. Nishida, S. Suda and M. Kobayashi, Hitachi Kasei Technical Report 47 (2007) 29-32 [in Japanese]. 